\title{
Metal Oxide Nanoparticle Based Electrochemical Sensor for Total Antioxidant Capacity (TAC) Detection in Wine Samples
}

\author{
Cristina Tortolini ${ }^{\circledR}$, Paolo Bollella, Rosaceleste Zumpano, Gabriele Favero, Franco Mazzei and \\ Riccarda Antiochia * (D) \\ Department of Chemistry and Drug Technologies, Sapienza University of Rome-P.le Aldo Moro 5, \\ 00185 Rome, Italy; cristina.tortolini@uniroma1.it (C.T.); paolo.bollella@uniroma1.it (P.B.); \\ rosaceleste.zumpano@uniroma1.it (R.Z.); gabriele.favero@uniroma1.it (G.F.); \\ franco.mazzei@uniroma1.it (F.M.) \\ * Correspondence: riccarda.antiochia@uniroma1.it
}

Received: 13 September 2018; Accepted: 9 November 2018; Published: 14 November 2018

\begin{abstract}
A single-use electrochemical screen-printed electrode is reported based on biomimetic properties of nanoceria particles (CeNPs). The developed tool showed an easy approach compared to the classical spectrophotometric methods reported in literature in terms of ease of use, cost, portability, and unnecessary secondary reagents. The sensor allowed the detection of the total antioxidant capacity (TAC) in wine samples. The sensor has been optimized and characterized electrochemically and then tested with antioxidant compounds occurred in wine samples. The electrochemical CeNPs modified sensor has been used for detection of TAC in white and red commercial wines and the data compared to the 2,2'-azino-bis(3-ethylbenzthiazoline-6-sulphonic acid (ABTS)-based spectrophotometric method. Finally, the obtained results have demonstrated that the proposed sensor was suitable for the simple and quick evaluation of TAC in beverage samples.
\end{abstract}

Keywords: total antioxidant capacity; antioxidants; nanoceria; enzyme mimetic; SPE sensor; disposable sensor; wine

\section{Introduction}

Antioxidant capacity is an ability of organisms or food to catch free radicals and prevent their harmful effects. Substances with antioxidative properties are called antioxidants and have received much attention in recent years. They have ability to fight against the oxidative processes [1], to promote health and to prevent a wide variety of diseases: atherosclerosis, type 2 diabetes, neurodegeneration (Alzheimer's and Parkinson's diseases) [2,3] and cancer [4]. Epidemiological studies recommend to introduce in the diet substances as fruits, vegetables and less processed staple foods ensure the best protection against possible diseases caused by oxidative stress, such as coronary heart disease, obesity, hypertension, and cataracts [5]. The explanation consists in the beneficial health effect, due to antioxidants present in fruit and vegetables [6]. In particular, polyphenols are naturally-occurring antioxidants found widely in the fruits, vegetables, cereals, dry legumes, chocolate and beverages, such as tea, coffee, or wine. Polyphenols and other food phenolics are the subject of increasing scientific interest because offer a great hope for the prevention of human diseases [7].

Total antioxidant capacity (TAC) is the measure of the quantity of free radicals scavenged by a test solution [8], for evaluating the antioxidant capacity in samples of different nature. Several methods have been proposed for the determination of the TAC of body fluids [9-13], of biological samples $[14,15]$, and food extracts $[16,17]$. Usually, the antioxidant capacity is 
given as the Trolox (6-hydroxy-2,5,7,8-tetramethylchroman-2-carboxylic acid) equivalent antioxidant capacity (TEAC) [18,19], as the ferric reducing antioxidant power (FRAP) [20,21], as the cupric reducing antioxidant capacity (CUPRAC) [22-24], as the oxygen radical absorption capacity method (ORAC) [25,26], as the 2,2'-azino-bis(3-ethylbenzthiazoline-6-sulphonic acid (ABTS) [25], and as the DPPH (2,2-diphenyl-1-picrylhydrazyl) method [27], respectively based on the different spectrophotometric methods which have been used to estimated it.

Recently, also electrochemical methods have greatly contributed to measure of TAC based on biosensors [28-31] and sensors [32,33]. They offer sensitivity, inexpensive instrumentation, fast response, small volumes [34-37].

In the last years, the application of nanomaterials resulted in many advantages for the sensing systems, including the observation of enhanced electrocatalytic phenomena with benefits in chemical and biosensing and improving analytical performance of classical sensing platforms [37-46]. Some authors reported nanomaterial based sensor for determination of polyphenols in foodstuffs [47-55].

Different kinds of nanomaterials have been used as stable and low-cost alternatives to biomolecules in (bio)analytical methods. The materials comprise metal/metal oxides, metal complexes, nanocomposites, porphyrins, phthalocyanines, smart polymers, and carbon nanomaterials [56,57]. Cerium oxide nanoparticles (CeNPs) or nanoceria particles have attractive catalytic and electrochemical features [58]. Moreover, ceria is an excellent co-immobilization material for a variety of oxidase and peroxidase enzymes such as horseradish peroxidase [59,60], glutamate oxidase [61]. Its catalytic activity can be exploited to develop highly sensitive, enzymeless $\mathrm{H}_{2} \mathrm{O}_{2}$ sensors [62] and for the fabrication of third generation biosensors [63]. Ceria has high oxygen mobility at its surface [64,65] and a large oxygen diffusion coefficient, which facilitates the conversion between valance states $\mathrm{Ce}^{4+} / \mathrm{Ce}^{3+}[66]$ that allow oxygen to be released or stored in its crystalline structure $[67,68]$.

Recently, CeNPs have also been reported to have multienzyme, including superoxide oxidase, catalase and oxidase, and mimetic properties [69-71], and have emerged as a fascinating material in biological fields, such as in bioanalysis [72-74], biomedicine [75-77], and drug delivery [78,79]. Catalytically active nanoceria offer several advantages over natural enzymes, such as controlled synthesis at low cost, tunable catalytic activities and high stability against severe physiological conditions [80].

In the present work, we developed an electrochemical disposable sensor modified with nanoceria particles for determination of total antioxidant capacity (TAC) in real samples. Firstly, the sensor was characterized electrochemically and then has been tested for some common antioxidants present in wines, such as gallic acid, caffeic acid, ascorbic acid, quercetin, trans-resveratrol and, finally, for the detection of TAC in six white and red commercial wine samples. The results relative to wine samples obtained with the electrochemical method were compared to those carried out with the spectrophotometric method (ABTS-based method). The modification procedure was demonstrated to be very simple and the developed sensor resulted to be easy-to-use, robust and cheap without involving labeled reagents.

\section{Materials and Methods}

\subsection{Chemicals and Reagents}

All chemicals used were analytical grade and were used as received without any further purification. In particular: sodium monobasic phosphate $\left(\mathrm{Na}_{2} \mathrm{HPO}_{4}\right)$, sodium dibasic phosphate $\mathrm{NaH}_{2} \mathrm{PO}_{4}$, potassium chloride $(\mathrm{KCl})$, potassium ferricyanide (III) $\left(\mathrm{K}_{3}\left[\mathrm{Fe}(\mathrm{CN})_{6}\right]\right)$, cerium (IV) oxide NPs (20 wt $\%$ colloidal dispersion in acetic acid $2.5 \mathrm{wt} \%, \mathrm{~d}=30-60 \mathrm{~nm}$ ), gallic acid $(\mathrm{GA})$, caffeic acid (CA), quercetin (Q), trans-resveratrol (t-R), ascorbic acid (AA), and dimethyl sulfoxide were purchased from Sigma-Aldrich (Buchs, Switzerland). For the TEAC assay: 2,2'-azino-bis(3-ethylbenzothiazoline-6-sulphonic acid (ABTS) and potassium persulfate $\left(\mathrm{K}_{2} \mathrm{~S}_{2} \mathrm{O}_{8}\right)$ were also supplied by Sigma-Aldrich (Buchs, Switzerland). 
All the solutions were prepared in phosphate buffer $0.1 \mathrm{M}, \mathrm{KCl} 0.1 \mathrm{M}, \mathrm{pH} 7.4$ (PBS buffer) high-purity deionized water (resistance: $18.2 \mathrm{M} \Omega \times \mathrm{cm}$ at $25{ }^{\circ} \mathrm{C}$; TOC $<10 \mu \mathrm{g} \mathrm{L}^{-1}$ ) obtained from Millipore (Molsheim, France) has been used to prepare all the solutions.

A solution of $1.1 \mathrm{mM} \mathrm{K}_{3}\left[\mathrm{Fe}(\mathrm{CN})_{6}\right]$ in PBS buffer was used in cyclic voltammetric experiments for determination of electroactive area using the Randles-Ševćik equation. Stock solutions of $10 \mathrm{mM}$ of several phenolic (GA, CA, Q and t-R) and not phenolic antioxidants (AA) were prepared daily before use: all substances in PBS buffer only the quercitin had need of few drops of DMSO.

The value of $\mathrm{pH} 7.4$ was chosen because from early studies in literature was reported that at this value the particles have the highest oxidase-like activity against phenolic compounds [81]. Moreover, all the experiments were carried out at room temperature, approximately $25^{\circ} \mathrm{C}$.

\subsection{Electrochemical Measurements}

Electrochemical measurements were performed using a portable PalmSens potentiostat (PalmSens, Houten, The Netherlands) controlled by means of the PSTrace 4 program (Vers. 4.4 PalmSens BV). All the experiments were conducted using a three screen-printed electrodes system from Orion High Technologies S.L. (Parla, Madrid, Spain). In particular: Nanostructured carbon (OHT-000), carboxylic acid functionalized multi-walled carbon nanotubes (OHT-069) and Carboxylic acid functionalized multi-walled carbon nanotubes- $\mathrm{Fe}_{3} \mathrm{O}_{4}$ superparamagnetic nanoparticles (OHT-102) screen printed electrodes, respectively. The working electrodes were different for each sensor (with a surface diameter of $4 \mathrm{~mm}$ ) but the counter electrode (graphite) and the reference one $(\mathrm{Ag} / \mathrm{AgCl})$ were the same for all the SPEs.

All absorbance measurements were made at the specified wavelength $(731 \mathrm{~nm})$ of the selected spectrophotometric method (ABTS-based method) using a T60U Spectrometer PG Instruments Ltd. (Wibtoft Leicestershire, Lutterworth, UK).

\subsection{Electrochemical Method}

The procedure of square wave voltammetry (SWV) was carried out as analytical technique to develop the calibration curve of GA used as standard and to test the selected wine samples and for the other antioxidant compounds. The frequency (f) and pulse amplitude at $25 \mathrm{~Hz}$ and $50 \mathrm{mV}$, respectively. The OHT-069 modified SPE was used as sensor.

\subsection{Sensor Modification by Using CeNPS}

The surface modification procedure was realized by two steps: first, a colloidal NPs suspension of $2 \%(w / v)$ nanoceria was prepared by dispersing particles in distilled water, then $5 \mu \mathrm{L}$ of the solution were dropped onto the working electrode surface of the SPE and let it dry for two days at room temperature until use. Electrodes were stored at room temperature.

\subsection{ABTS-Based Method}

The ABTS antioxidant assay was slightly modified and carried out as described in literature [82]. Briefly, $7 \mathrm{mM}$ ABTS solution prepared in $2.5 \mathrm{mM} \mathrm{K}_{2} \mathrm{~S}_{2} \mathrm{O}_{8}$ was incubated in the dark for about $15 \mathrm{~h}$ at room temperature to generate ABTS radicals. Then, the solution was diluted 400 times with distilled water. The white wines and the red ones were diluted 10 and 100 times respectively with distilled water. Next $100 \mu \mathrm{L}$ of each sample were mixed with $2.5 \mathrm{~mL}$ of ABTS radical solution and $0.4 \mathrm{~mL} \mathrm{H}_{2} \mathrm{O}$ and the absorbance has read after $3 \mathrm{~min}$ at $731 \mathrm{~nm}$. The phenolic antioxidant gallic acid (GA) was used as standard, and triplicates were analysed for each sample. 


\section{Results and Discussion}

\subsection{Electrochemical Characterization}

\subsubsection{Comparison of Electrochemical Performances before and after CeNPs Sensor Modification}

Firstly, the improvement of the electrochemical performances by the simple modification of the electrode surface using CeNPs has been demonstrated by calculating the electroactive area $\left(\mathrm{A}_{\mathrm{e}}\right)$ of three different SPE sensors.

The $\mathrm{A}_{\mathrm{e}}$ for the electrodes were obtained by cyclic voltammetry $(\mathrm{CV})$ using a solution of $1.1 \mathrm{mM}$ $\mathrm{K}_{3}\left[\mathrm{Fe}(\mathrm{CN})_{6}\right]$ in PBS buffer solution as probe at different scan rates. For a reversible process, the Randles-Ševćik equation has been used:

$$
\mathrm{I}_{\mathrm{p}}=2.68610^{5} \mathrm{n}^{3 / 2} \mathrm{~A}_{\mathrm{e}} \mathrm{D}_{0}^{1 / 2} \mathrm{C}_{0} \mathrm{v}^{1 / 2}
$$

where $I_{p}$ is peak current in ampere $(A), n$ is number of electrons transferred of $K_{3}\left[\mathrm{Fe}(\mathrm{CN})_{6}\right]$ by $C V$ in the redox event (usually 1), $A_{e}$ is electroactive area $\left(\mathrm{cm}^{2}\right), D_{0}$ is diffusion coefficient $\left(7.6 \times 10^{-6} \mathrm{~cm}^{2} \mathrm{~s}^{-1}\right)$, $\mathrm{C}_{0}$ is the concentration $\left(\mathrm{mol} \mathrm{cm}{ }^{-3}\right)$, and $\mathrm{v}$ is the scan rate $\left(\mathrm{Vs}^{-1}\right)$ [83]. By using the slope of the plot of $I_{p}$ vs $v^{1 / 2}$, the electroactive areas were calculated and the results are shown in Table 1 . In bare OHT-000, OHT-102, and OHT-069 SPEs, the electrode surface was found to be: $2.42,6.26$, and $8.50 \mathrm{~mm}^{2}$ respectively. For the same modified SPEs the surface was nearly 7, 3, and 2.5 times greater. The presence of the MWCNTs in both OHT-102 and OHT-069 bare sensors resulted in a higher $\mathrm{A}_{\mathrm{e}}$ value in comparison to OHT-000 bare sensor, due to the well-known peculiarities of nanomaterials (e.g., large surface-to-volume ratios, their physicochemical properties, composition, and shape and their robustness, etc.) $[39,40]$. Moreover, the modification procedure of the different working electrode surface by the presence of cerium nanoparticles increased quite notable the peak current signal and consequently the surface activity. This was attributed to their capability to facilitate the electron transfer [60] and to improve the biocatalytic signals [84].

Table 1. Comparison of the electroactive area $\left(\mathrm{A}_{\mathrm{e}}\right)$ before and after CeNPs modification.

\begin{tabular}{ccccc}
\hline Sensor & $\left.\mathbf{A}_{\mathbf{e}}{ }^{\mathbf{a}} \mathbf{( m m}^{\mathbf{2}}\right)$ & $\mathbf{A}_{\mathbf{e}}{ }^{\mathbf{b}}\left(\mathbf{m m}^{\mathbf{2}}\right)$ & $\boldsymbol{\rho}^{\mathbf{a}}$ & $\boldsymbol{\rho}^{\mathbf{b}}$ \\
\hline OHT-000 & $2.42 \pm 0.02$ & $16.82 \pm 0.04$ & 0.19 & 1.34 \\
OHT-102 & $6.26 \pm 0.02$ & $18.74 \pm 0.02$ & 0.50 & 1.49 \\
OHT-069 & $8.50 \pm 0.03$ & $21.93 \pm 0.01$ & 0.68 & 1.74 \\
\hline
\end{tabular}

${ }^{\mathrm{a}}$ Bare sensor; ${ }^{\mathrm{b}}$ modified sensor by using $5 \mu \mathrm{L}$ CeNPs solution on the electrode surface.

In addition, the comparison was also observed in function of PBS buffer solution (Figure 1) and one of the selected antioxidants, the caffeic acid (Figure 2). The modified electrode had no electrochemical activity in phosphate buffer solution (Figure 1A,B, black lines) and showed a similar CV profile to the bare electrodes, respectively (Figure 1A,B, red lines). Conversely, for the OHT-102 a couple of peaks was observed (Figure $1 \mathrm{C}$, black line), probably due to $\mathrm{Fe}_{3} \mathrm{O}_{4}$ nanoparticles redox behaviour, which are directly reduced at the electrode surface according to the following reaction:

(1) $\mathrm{Fe}_{3} \mathrm{O}_{4}(\mathrm{~s})+2 \mathrm{e}^{-}+6 \mathrm{H}^{+}(\mathrm{aq}) \rightarrow 2 \mathrm{Fe}^{2+}(\mathrm{aq})+3 \mathrm{H}_{2} \mathrm{O}+\mathrm{FeO}(\mathrm{s})$

Then, $\mathrm{Fe}^{2+}$ ions produced could combine with phosphate ions in the buffer solution:

(2) $\mathrm{Fe}^{2+}(\mathrm{aq})+\mathrm{HPO}_{4}^{2-}(\mathrm{aq}) \rightarrow \mathrm{FePO}_{4}(\mathrm{~s})+\mathrm{e}^{-}+\mathrm{H}^{+}(\mathrm{aq})$

Here after, the solid $\mathrm{FePO}_{4}$ at the surface of electrode could be responsible for observed redox behaviour $[85,86]$. For all the three modified sensors the background current becomes larger, due to the CeNPs can increase the surface activity remarkably. The CeNPs-induced oxidation of CA was studied in the potential range between -0.4 and $0 \mathrm{~V}$, as example in Figure 2 is reported the electrochemical performance of the OHT-069 SPE sensor. The CVs of bare and modified SPE carried out in PBS buffer 
solution showed a similar voltammogram, but in the case of the CeNPs modified sensor the area was broader and it showed no peaks in PBS indicating lack of electrochemical activity of these cerium particles in the potential range tested (Figure 2, red line). Observing the electrochemical behaviour of the bare OHT-069 SPE (Figure 2, green line) and the modified one (Figure 2, blue line) in the presence of $0.8 \mu \mathrm{M}$ CA solution a similar profile is recorded. Anodic and catodic peaks were observed in both cases. In the CV of the CeNPs/SPE the peaks are wider and shifted to higher potential values compared to those observed for the bare/SPE. In identical experimental conditions, sensors in presence of nanoparticles showed a more evident response in the same potential range comparing to bare carbon electrode. This difference demonstrates the role of CeNPs to catalytically form reducible quinones onto the electrode surface and, moreover, to be better able to quantitatively detect antioxidants.
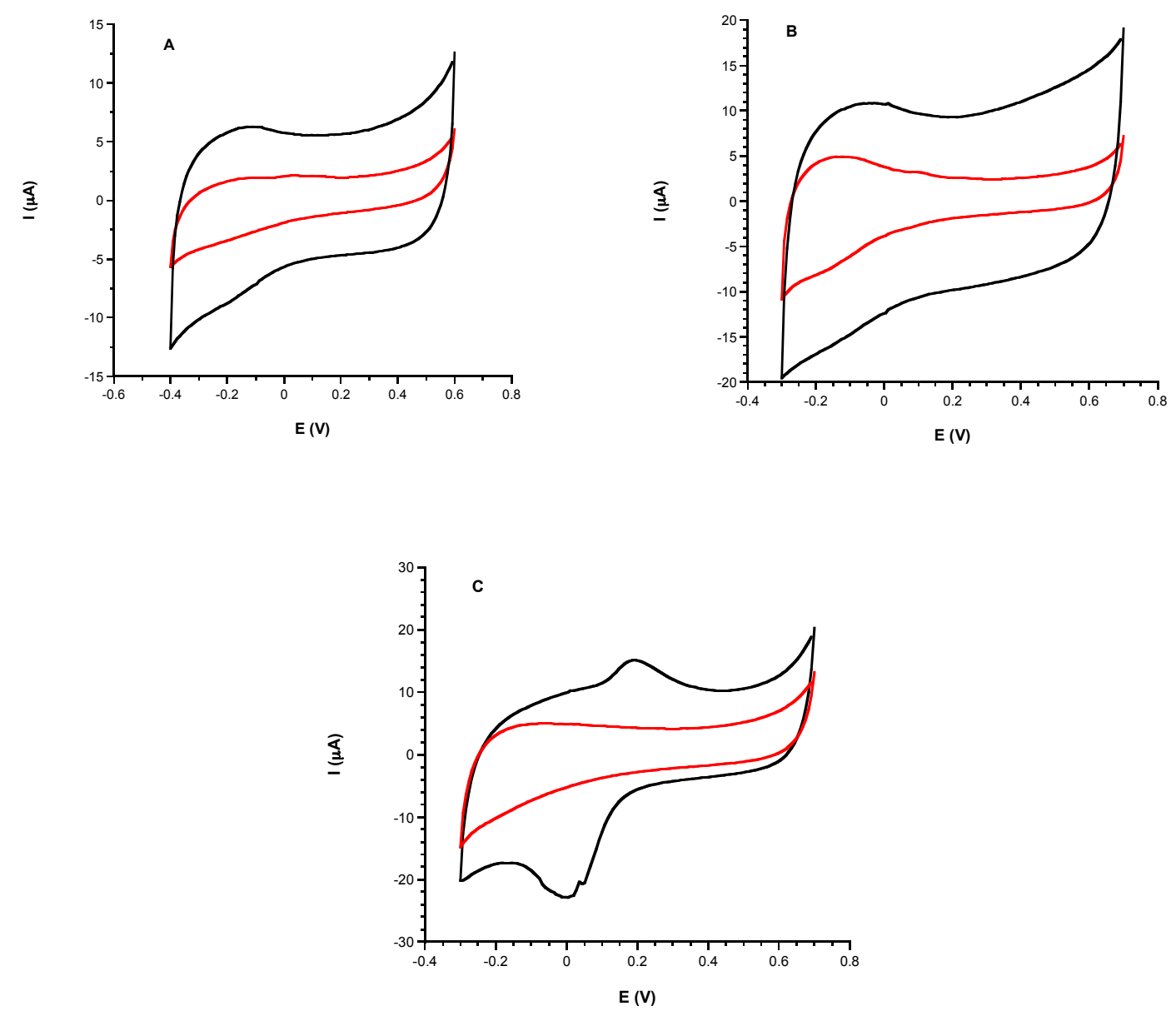

Figure 1. CVs of OHT-000 (A), OHT-069 (B), and OHT-102 (C) bare sensors (red line) and after modification by CeNPs (black line) in PBS buffer solution, $v=100 \mathrm{mV} \mathrm{s}^{-1}$. 


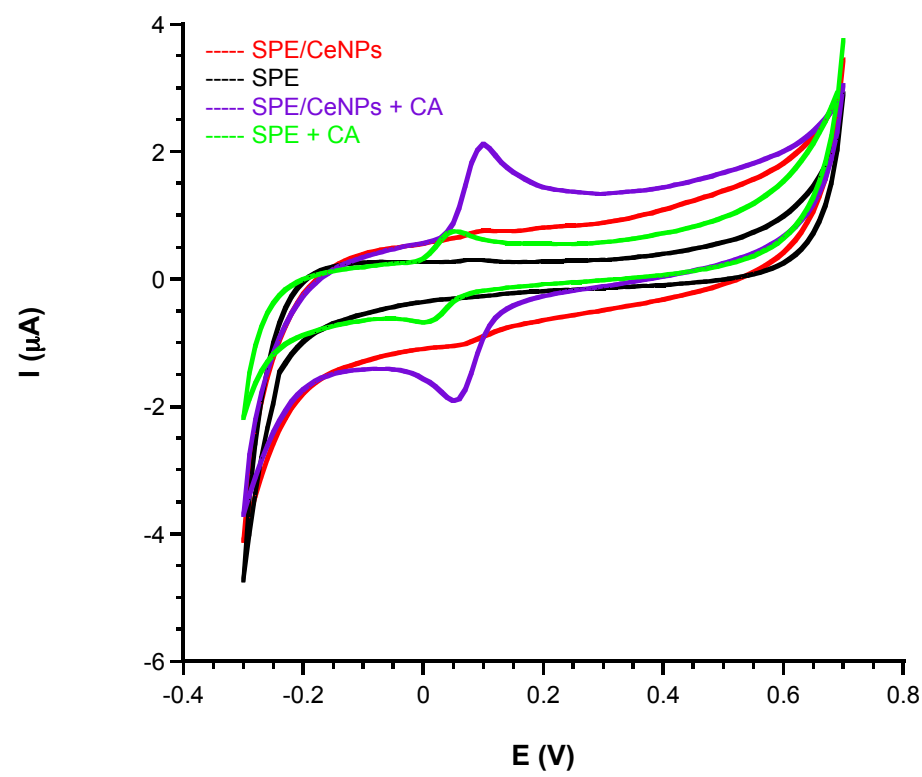

Figure 2. CVs of OHT-069 bare SPE (black line) and modified SPE by CeNPs (red line) in PBS buffer solution and the same sensors OHT-069 bare SPE (green line) and modified SPE by CeNPs (blue line) in the presence of $0.8 \mu \mathrm{M}$ di CA at $\nu=10 \mathrm{mV} \mathrm{s}^{-1}$.

The reduction current was proportional with the amount of $\mathrm{CA}$ added on the electrode, as illustrated in Figure 3. By increasing CA concentration from 5.5 to $550 \mu \mathrm{M}$, the oxidation/reduction peak potential is constant at 0.130 and $0.050 \mathrm{~V}$, respectively. These results suggest that diffusional barriers are not present for the oxidized/reduced CA to/from nanoceria surface. Figure 4 shows the effect of scan rate on the intensity of the oxidation/reduction current. In the inset of Figure 4 is reported the reduction current vs. the square root of scan rate. The current increased proportionally with the square root of scan rate with a correlation coefficient of $0.99(\mathrm{~N}=3)$ with a slight shift towards negative potentials, suggesting a quasi-reversible process, which is diffusion-controlled.

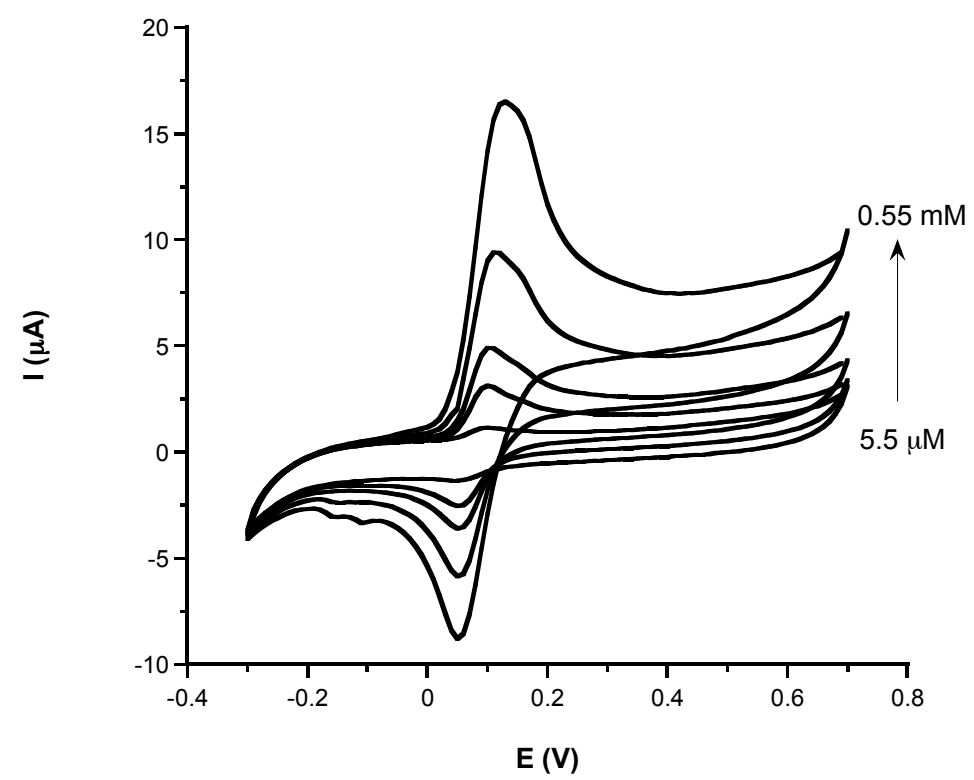

Figure 3. CVs of modified OHT-069 SPE in presence of different CA concentrations: 5.5, 45, 120, 270, and $550 \mu \mathrm{M}$, at $v=10 \mathrm{mV} \mathrm{s}^{-1}$. 


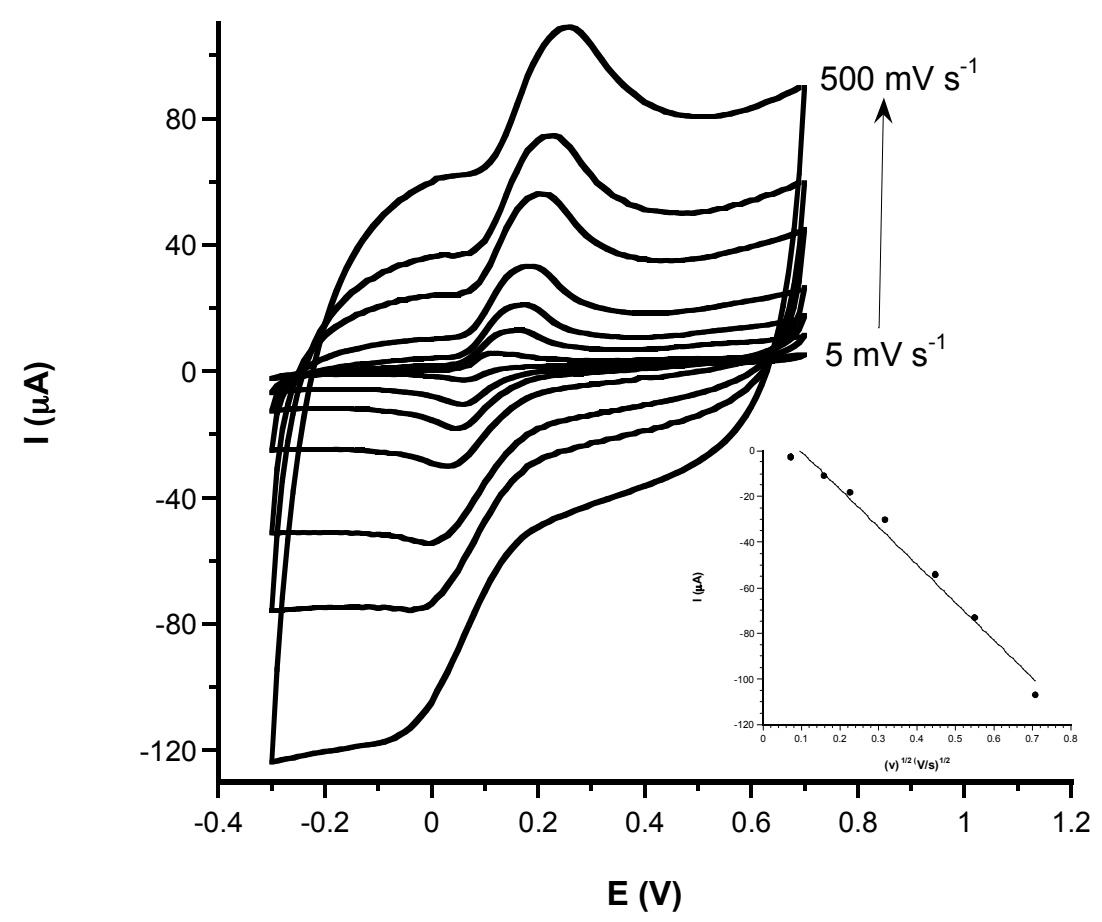

Figure 4. CVs of CA $550 \mu \mathrm{M}$ using the modified OHT-069 SPE recorded in PBS buffer solution at scan rates of: $5,25,50,100,200,300$, and $500 \mathrm{mV} \mathrm{s}^{-1}$, respectively. Inset: plot of reduction current vs. the square root of scan rate.

3.1.2. Analytical Characteristic: Sensitivity, LOD, Linear Range, and Response Time of Phenolic and Non-Phenolic Antioxidants

The CeNPs modified sensors have been tested for the detection of some common antioxidant compounds contained in wines: gallic acid (GA), caffeic acid (CA), quercetin (Q), t-resveratrol (t-R), and ascorbic acid (AA).

Figure 5 displays the calibration curves of the three different sensors for the selected antioxidant compounds. After the addition of the antioxidant compound a response proportional with the concentration was observed.

The sensitivity of the different sensors towards the same antioxidant was studied and the results reported in Figure 5A-E. The order OHT-069 > OHT-102 > OHT-000 was observed. 

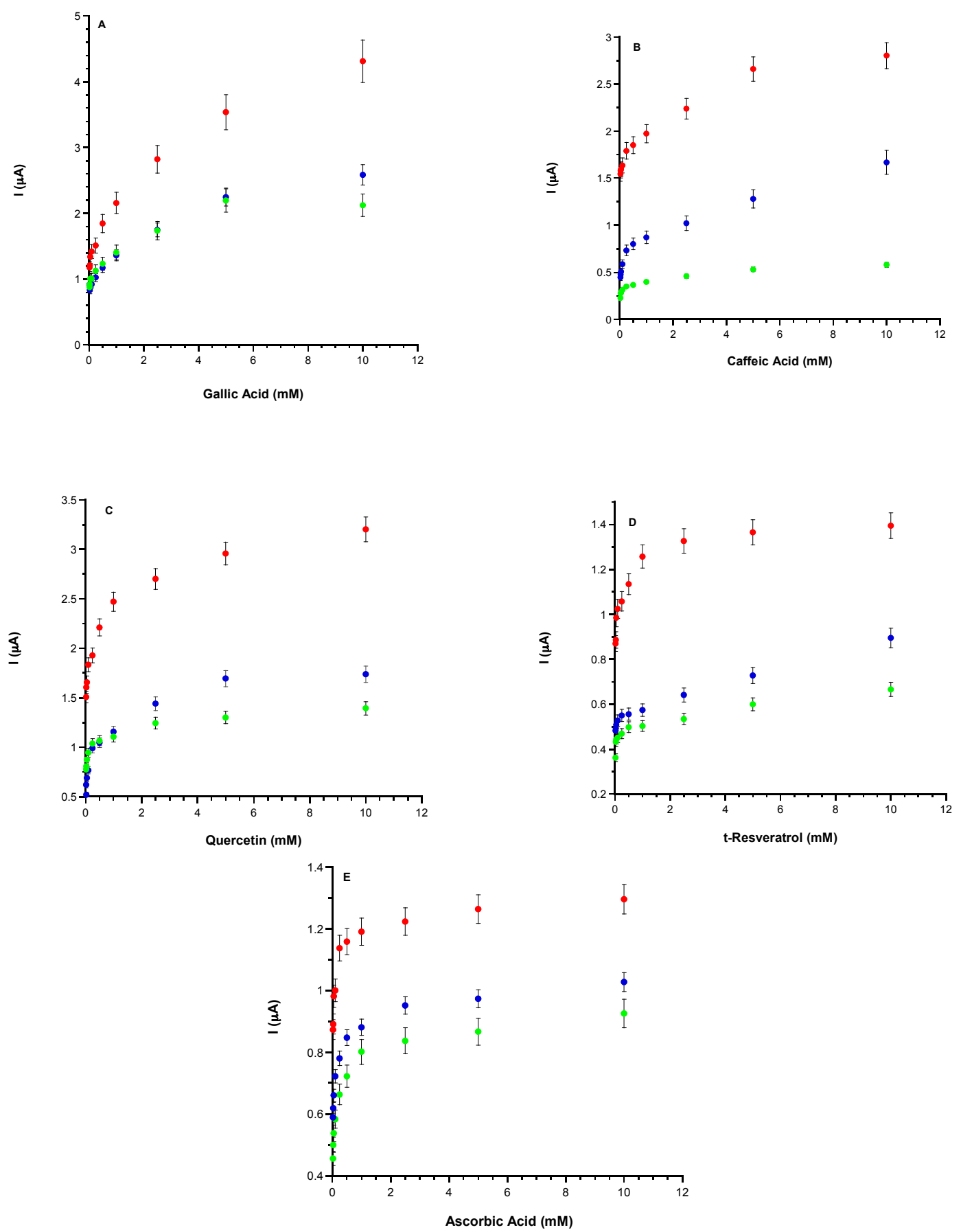

Figure 5. Calibration curves for antioxidant compounds employing SWV technique: gallic acid, GA (A), caffeic acid, CA (B), quercetin, Q (C), t-resveratrol, t-R (D), and ascorbic acid, AA (E) at different concentrations. The modified SPE-sensors are: OHT-069 (red circle), OHT-102 (blue circle), and OHT-000 (red circle), respectively.

The analytical parameters of the antioxidants have been reported by applying the CeNPs modified OHT-069 sensor (Table 2). 
Table 2. Analytical characterization of antioxidant compounds by using CeNPs modified OHT-069 sensor by SWV method.

\begin{tabular}{cccccc}
\hline Antioxidant Compound & \multicolumn{2}{c}{ Linear Range $(\mathbf{m M})$} & Slope $\left(\boldsymbol{\mu} \mathbf{A ~} \mathbf{m M}^{-\mathbf{1}}\right)$ & $\mathbf{R}$ & \multicolumn{2}{c}{ LOD $(\mathbf{m M})$} \\
\hline \multirow{2}{*}{ GA } & LLR & $0.025-0.05$ & 6.55 & 0.990 & 0.007 \\
& HLR & $0.5-5.0$ & 0.57 & 0.987 & 0.151 \\
\hline \multirow{2}{*}{ CA } & LLR & $0.033-0.1$ & 0.793 & 0.999 & 0.010 \\
& HLR & $0.25-5.0$ & 0.180 & 0.998 & 0.083 \\
\hline \multirow{2}{*}{$\mathrm{Q}$} & LLR & $0.025-0.1$ & 3.978 & 0.978 & 0.009 \\
& HLR & $1.0-5.0$ & 0.120 & 0.994 & 0.303 \\
\hline \multirow{2}{*}{$\mathrm{t}-\mathrm{R}$} & LLR & $0.025-0.05$ & 4.791 & 0.982 & 0.008 \\
& HLR & $0.1-1.0$ & 0.262 & 0.999 & 0.033 \\
\hline \multirow{2}{*}{ AA } & LLR & $0.025-1$ & 1.667 & 0.999 & 0.007 \\
& HLR & $1.0-5.0$ & 0.180 & 0.996 & 0.334 \\
\hline
\end{tabular}

LLR: Low Linear Range; HLR: High Linear Range.

\subsection{Spectrophotometric Characterization}

The ABTS-based assay described here involves the direct production of the blue/green ABTS ${ }^{\bullet+}$ chromophore. This has absorption maxima at $731 \mathrm{~nm}$. The addition of antioxidant compounds quenches the colour and produce a decolouration of the solution which is proportional to their amount (Scheme 1). This reaction is rapid and the end point, which is stable, is taken as a measure of the antioxidative efficiency.

$$
\begin{gathered}
\text { ABTS (uncolored) }+ \text { Reagent } \rightarrow \text { ABTS } \bullet+(\text { blue/green })\left(\lambda_{\max }=731 \mathrm{~nm}\right) \\
\text { ABTS•+(blue/green) }+\mathrm{AOH} \rightarrow \text { ABTS (uncolored })+\mathrm{AO}
\end{gathered}
$$

Scheme 1. Formation of radical ABTS and its reaction with antioxidants (AOH).

The phenolic antioxidant Gallic Acid (GA) was used as standard and the values of real samples expressed as $\mathrm{mg} \mathrm{L}^{-1}$ of GA.

In Table 3 we have reported a comparison with some enzyme-based biosensors and nanomaterial-based sensors for the determination of some common antioxidants, present in the literature [50,57,87-92]. The linear range of our developed sensor is similar and, in some cases, better than ones proposed by other authors. In terms of storage, our sensor is superior respect to the enzyme biosensors because no needs of storage conditions, on the contrary enzyme-based biosensors need of particular conditions (e.g., buffer and low temperature) and one of their drawbacks is protein instability $[50,88,90]$. Furthermore, in comparison to the nanomaterial CeNP-modified electrode for GA and AA compounds our linear range is broader [57]. Additionally, our LOD value is lower for $C A$ and $Q$ antioxidants [57]. In terms of response time, we have recorded a response time of $30 \mathrm{~s}$. Lastly, these advantages make our sensor as a useful tool for a quick screening to detect antioxidants in beverages sample. 
Table 3. Comparison of some analytical characteristics for antioxidants detection of some enzyme-based biosensors and nanomaterial-based sensors.

\begin{tabular}{|c|c|c|c|c|c|}
\hline Sensor & $\begin{array}{l}\text { Antioxidant } \\
\text { Compound }\end{array}$ & $\operatorname{LR}(\mu \mathrm{M})$ & LOD $(\mu \mathrm{M})$ & $\begin{array}{l}\text { Storage/Response } \\
\text { Time }\end{array}$ & Ref. \\
\hline $\mathrm{Lac} / \mathrm{pESm} / \mathrm{Pt}$ electrode & $\mathrm{CA}$ & $10-80$ & - & - & [87] \\
\hline $\mathrm{Lac} / \mathrm{PAP} / \mathrm{SWCNTs} / \mathrm{SPE}$ & GA & $0.53-96$ & - & $10 \mathrm{~d}$ at $4{ }^{\circ} \mathrm{C} /-$ & [88] \\
\hline Lac/oxygen electrode & \multirow{2}{*}{ CA } & $0.10-1.00$ & 0.06 & - & \multirow{2}{*}{ [89] } \\
\hline $\mathrm{Lac} / \mathrm{Fc} / \mathrm{SPE}$ & & $2.0-30.0$ & 1.6 & - & \\
\hline Tyr/BSA/GA/Fc/SPE & $\begin{array}{l}\text { GA } \\
\text { CA }\end{array}$ & $\begin{array}{l}30.0-300 \\
10.6-266\end{array}$ & $\begin{array}{c}57 \\
10.5\end{array}$ & $30 \mathrm{~d}$ at $4{ }^{\circ} \mathrm{C} /-$ & [90] \\
\hline $\begin{array}{l}\text { ITO/Lac/Tyr/CS/MWCNTs } \\
\text { electrode }\end{array}$ & $\begin{array}{l}\text { GA } \\
\text { CA }\end{array}$ & $\begin{array}{l}1.6-8.1 \\
0.4-7.4\end{array}$ & $\begin{array}{l}1.5 \\
0.3\end{array}$ & $\begin{array}{l}8 \mathrm{~d} \text { at } 4{ }^{\circ} \mathrm{C} \text { dry } \\
\text { atmosphere/- }\end{array}$ & [50] \\
\hline $\begin{array}{c}\mathrm{POx} / \mathrm{Fc} / \mathrm{MWCNTs} / \mathrm{MO} \\
\text { electrode }\end{array}$ & $\begin{array}{l}C A \\
t-R\end{array}$ & $\begin{array}{l}0.3-383 \\
0.2-228 \\
\end{array}$ & $\begin{array}{l}0.1 \\
0.1\end{array}$ & - & [91] \\
\hline GC/MWCNTs/PEI/electrode & $\begin{array}{c}\text { GA } \\
\text { CA } \\
Q \\
\end{array}$ & $\begin{array}{c}0.6-12 \\
0.6-12 \\
0.3-6 \\
\end{array}$ & $\begin{array}{l}0.04 \\
0.08 \\
0.03\end{array}$ & - & [92] \\
\hline CeNPs/C/SPE & $\begin{array}{c}\text { GA } \\
\text { CA } \\
\text { Q } \\
\text { AA }\end{array}$ & $\begin{array}{c}2-20 \\
50-100 \\
20-200 \\
0.5-20\end{array}$ & $\begin{array}{c}1.5 \\
15.3 \\
8.6 \\
0.4 \\
\end{array}$ & $\mathrm{RT} / 40 \mathrm{~s}$ & [57] \\
\hline CeNPs/MWCNTs-COOH/SPE & $\begin{array}{c}\text { GA } \\
\text { CA } \\
Q \\
t-R \\
\text { AA }\end{array}$ & $\begin{array}{c}25-50 \\
33-100 \\
25-100 \\
25-50 \\
25-100\end{array}$ & $\begin{array}{c}7 \\
10 \\
8 \\
8 \\
7\end{array}$ & $\mathrm{RT} / 30 \mathrm{~s}$ & Our work \\
\hline
\end{tabular}

Lac: Laccase; pESm: polyether sulphone membrane; PAP: polyazetidine prepolymer; Fc: ferrocene; Tyr: tyrosinase; CS: chitosan; BSA: bovine serum albumine; GA: glutaraldehyde; PEI: polyethylenimine; POx; peroxidase; MO: mineral oil; C: carbon.

\subsection{Real Sample Analysis}

Real samples (common antioxidants and white/red commercial wines) were tested for their antioxidant activity. The real samples were analysed both by the OHT-069-modified sensor and the ABTS-based assay.

By the first method, the antioxidant activity of the wine sample was reported as $\mathrm{mg} \mathrm{L}^{-1}$ of GA, obtained by interpolation of the current signal of the sample into the calibration curve of the GA. The wine white sample were diluted 10 times before analysis and the red ones 100.

For comparison purpose, the same samples were also analysed by the spectrophotometric method involving the use of the ABTS to calculate the total antioxidant capacity (TAC).

As reported in Table 4, the data obtained with the two methods are in good agreement despite the electrochemical and the spectrophotometric methods are based on a completely different mechanism. The results relative to white and red wines are in very close agreement with the data obtained with the spectrophotometric test. Finally, we can conclude that the nanoceria modified sensor could be employed as first tool for the determination of TAC in wine samples. It can be considered as a valid alternative to commercially available spectrophotometric kits thanks to several advantages such as ease of use, rapidity, cost-effectiveness, and portability. 
Table 4. TAC of several white and red wines assessed in parallel by the nanoceria-based electrochemical assay and by the classic TEAC assay.

\begin{tabular}{ccc}
\hline Wine Sample & CeNPs-SPE $^{\text {a }}$ & ABTS-Based Method $^{\text {a }}$ \\
\hline white 1 & $204 \pm 10$ & $208 \pm 17$ \\
white 2 & $183 \pm 11$ & $187 \pm 9$ \\
white 3 & $212 \pm 18$ & $209 \pm 15$ \\
red 1 & $2067 \pm 207$ & $2078 \pm 187$ \\
red 2 & $2340 \pm 210$ & $2538 \pm 228$ \\
red 3 & $3938 \pm 236$ & $4172 \pm 292$ \\
\hline
\end{tabular}

${ }^{\text {a }}$ Expressed as $\mathrm{mg} \mathrm{L}^{-1}$ of GA.

Author Contributions: Conceptualization, C.T. and P.B.; Formal Analysis, R.Z.; Investigation, C.T.; Resources, F.M.; Data Curation, G.F.; Writing-Original Draft Preparation, C.T.; Writing-Review \& Editing, P.B. and R.A.; Visualization, G.F.; Supervision, F.M.

Funding: This research received no external funding.

Conflicts of Interest: The authors declare no conflict of interest.

\section{References}

1. Pisoschi, A.M.; Pop, A. The role of antioxidants in the chemistry of oxidative stress: A review. Eur. J. Med. Chem. 2015, 97, 55-74. [CrossRef] [PubMed]

2. Uttara, B.; Singh, A.V.; Zamboni, P.; Mahajan, R.T. Oxidative stress and neurodegenerative diseases: A review of upstream and downstream antioxidant therapeutic options. Curr. Neuropharmacol. 2009, 7, 65-74. [CrossRef] [PubMed]

3. D'Angelo, B.; Santucci, S.; Benedetti, E.; Di Loreto, S.; Phani, R.A.; Falone, S.; Amicarelli, F.; Ceru, M.P.; Cimini, A. Cerium oxide nanoparticles trigger neuronal survival in a human Alzheimer disease model by modulating BDNF pathway. Curr. Nanosci. 2009, 5, 167-176. [CrossRef]

4. Tian, Z.; Li, J.; Zhang, Z.; Gao, W.; Zhou, X.; Qu, Y. Highly sensitive and robust peroxidase-like activity of porous nanorods of ceria and their application for breast cancer detection. Biomaterials 2015, 59, 116-124. [CrossRef] [PubMed]

5. Halvorsen, B.L.; Holte, K.; Myhrstad, M.C.W.; Barikmo, I.; Hvattum, E.; Remberg, S.F.; Wold, A.B.; Haffner, K.; Baugerød, H.; Andersen, L.F.; et al. A systematic screening of total antioxidants in dietary plants. J. Nutr. 2002, 132, 461-471. [CrossRef] [PubMed]

6. Halvorsen, B.L.; Carlsen, M.H.; Phillips, K.M.; Bohn, S.K.; Holte, K.; Jacobs, D.R., Jr.; Blomhoff, R. Content of redox-active compounds (ie, antioxidants) in foods consumed in the United States. Am. J. Clin. Nutr. 2006, 84, 95-135. [CrossRef] [PubMed]

7. Scalbert, A.; Manach, C.; Morand, C.; Rémésy, C.; Jiménez, L. Dietary polyphenols and the prevention of diseases. Crit. Rev. Food Sci. Nutr. 2005, 45, 287-306. [CrossRef] [PubMed]

8. Ghiselli, A.; Serafini, M.; Natella, F.; Scaccini, C. Total antioxidant capacity as a tool to assess redox status: Critical view and experimental data. Free Radic. Biol. Med. 2000, 29, 1106-1114. [CrossRef]

9. Miller, N.J.; Rice-Evans, C.A.; Davies, M.J.; Gopinathan, V.; Milner, A. A novel method for measuring antioxidant capacity and its application to monitoring the antioxidant status in premature neonates. Clin. Sci. 1993, 84, 407-412. [CrossRef] [PubMed]

10. Ghiselli, A.; Serafini, M.; Maiani, G.; Azzini, E.; Ferro-Luzzi, A. A fluorescence-based method for measuring total plasma antioxidant capability. Free Radic. Biol. Med. 1995, 18, 29-36. [CrossRef]

11. Lonnrot, K.; Metsa-Ketela, T.; Molnar, G.; Ahonen, J.-P.; Latvala, M.; Peltola, J.; Pietila, T.; Alho, H. The effect of ascorbate and ubiquinone supplementation on plasma and CSF total antioxidant capacity. Free Radic. Biol. Med. 1996, 21, 211-217. [CrossRef]

12. Koracevic, D.; Koracevic, G.; Djordjevic, V.; Andrejevic, S.; Cosic, V. Method for the measurement of antioxidant activity in human fluids. J. Clin. Pathol. 2001, 54, 356-361. [CrossRef] [PubMed]

13. Cao, G.; Prior, R.L. Comparison of different analytical methods for assessing total antioxidant capacity of human serum. Clin. Chem. 1998, 44, 1309-1315. [PubMed] 
14. Marques, S.S.; Magalhães, L.M.; Tóth, I.V.; Segundo, M.A. Insights on antioxidant assays for biological samples based on the reduction of copper complexes-The importance of analytical conditions. Int. J. Mol. Sci. 2014, 15, 11387-11402. [CrossRef] [PubMed]

15. Bartosz, G. Non-enzymatic antioxidant capacity assays: Limitations of use in biomedicine. Free Radic. Res. 2010, 44, 711-720. [CrossRef] [PubMed]

16. Pinchuk, I.; Shoval, H.; Dotan, Y.; Lichtenberg, D. Evaluation of antioxidants: Scope, limitations and relevance of assays. Chem. Phys. Lipids 2012, 165, 638-647. [CrossRef] [PubMed]

17. Rice-Evans, C.A.; Miller, N.J. Antioxidant activities of flavonoids as bioactive components of food. Biochem. Soc. Trans. 1996, 24, 790-795. [CrossRef] [PubMed]

18. Zulueta, A.; Esteve, M.J.; Frigola, A. ORAC and TEAC assays comparison to measure the antioxidant capacity of food products. Food Chem. 2009, 114, 310-316. [CrossRef]

19. Re, R.; Pellegrini, N.; Proteggente, A.; Pannala, A.; Yang, M.; Rice-Evans, C. Antioxidant activity applying an improved ABTS radical cation decolorization assay. Free Radic. Biol. Med. 1999, 26, 1231-1237. [CrossRef]

20. Pellegrini, N.; Serafini, M.; Colombi, B.; Del Rio, D.; Salvatore, S.; Bianchi, M.; Brighenti, F. Total antioxidant capacity of plant foods, beverages and oils consumed in Italy assessed by three different in vitro assays. J. Nutr. 2003, 133, 2812-2819. [CrossRef] [PubMed]

21. Benzie, I.F.; Strain, J.J. The ferric reducing ability of plasma (FRAP) as a measure of "antioxidant power": The FRAP assay. Anal. Biochem. 1996, 239, 70-76. [CrossRef] [PubMed]

22. Ou, B.; Huang, D.; Hampsch-Woodill, M.; Flanagan, J.A.; Deemer, E.K. Analysis of antioxidant activities of common vegetables employing oxygen radical absorbance capacity (ORAC) and ferric reducing antioxidant power (FRAP) assays: A comparative study. J. Agric. Food Chem. 2002, 50, 3122-3128. [CrossRef] [PubMed]

23. Meng, J.; Fang, Y.; Zhang, A.; Chen, S.; Xu, T.; Ren, Z.; Han, G.; Liu, J.; Li, H.; Zhang, Z.; et al. Phenolic content and antioxidant capacity of Chinese raisins produced in Xinjiang Province. Food Res. Int. 2011, 44, 2830-2836. [CrossRef]

24. Apak, R.; Guculu, K.G.; Ozyurek, M.; Karademir, S.E. Novel total antioxidant capacity index for dietary polyphenols and vitamins $\mathrm{C}$ and $\mathrm{E}$, using their cupric iron reducing capability in the presence of neocuproine: CUPRAC method. J. Agric. Food Chem. 2004, 52, 7970-7981. [CrossRef] [PubMed]

25. Thaipong, K.; Boonprakob, U.; Crosby, K.; Cisneros-Zevallos, L.; Byrne, D.H. Comparison of ABTS, DPPH, FRAP, and ORAC assays for estimating antioxidant activity from guava fruit extracts. J. Food Compost. Anal. 2006, 19, 669-675. [CrossRef]

26. Denev, P.; Ciz, M.; Ambrozova, G.; Lojek, A.; Yanakieva, I.; Kratchanova, M. Solid phase extraction of berries' anthocyanins and evaluation of their antioxidative properties. Food Chem. 2010, 123, 1055-1061. [CrossRef]

27. Molyneux, P. The use of the stable free radical diphenylpicrylhydrazyl (DPPH) for estimating antioxidant activity. Songklanakarin J. Sci. Technol. 2004, 26, 211-219.

28. Gil, D.M.A.; Rebelo, M.J.F. Evaluating the antioxidant capacity of wines: A laccase-based biosensor approach. Eur. Food Res. Technol. 2010, 231, 303-308. [CrossRef]

29. Wang, X.; Jiao, C.; Yu, Z. Electrochemical biosensor for assessment of the total antioxidant capacity of orange juice beverage based on the immobilizing DNA on a poly l-glutamic acid doped silver hybridized membrane. Sens. Actuators B Chem. 2014, 192, 628-633. [CrossRef]

30. Barroso, M.F.; de-los-Santos-Álvarez, N.; Lobo-Castañón, M.J.; Miranda-Ordieres, A.J.; Delerue-Matos, C.; Oliveira, M.B.P.P.; Tuñón-Blanco, P. DNA-based biosensor for the electrocatalytic determination of antioxidant capacity in beverages. Biosens. Bioelectron. 2011, 26, 2396-2401. [CrossRef] [PubMed]

31. Barroso, M.F.; Delerue-Matos, C.; Oliveira, M.B.P.P. Electrochemical evaluation of total antioxidant capacity of beverages using a purine-biosensor. Food Chem. 2012, 132, 1055-1062. [CrossRef]

32. Blasco, A.J.; Crevillén, A.G.; González, M.C.; Escarpa, A. Direct electrochemical sensing and detection of natural antioxidants and antioxidant capacity in vitro systems. Electroanalysis 2007, 19, 2275-2286. [CrossRef]

33. Wang, Y.; Calas-Blanchard, C.; Cortina-Puig, M.; Baohong, L.; Marty, J.L. An electrochemical method for sensitive determination of antioxidant capacity. Electroanalysis 2009, 21, 1395-1400. [CrossRef]

34. Bhalla, N.; Jolly, P.; Formisano, N.; Estrela, P. Introduction to biosensors. Essays Biochem. 2016, 60, 1-8. [CrossRef] [PubMed]

35. Kimmel, D.W.; LeBlanc, G.; Meschievitz, M.E.; Cliffel, D.E. Electrochemical Sensors and Biosensors. Anal. Chem. 2012, 84, 685-707. [CrossRef] [PubMed]

36. Turner, A.P.F. Biosensors: Sense and sensibility. Chem.Soc. Rev. 2013, 42, 3184-3196. [CrossRef] [PubMed] 
37. Bollella, P.; Fusco, G.; Tortolini, C.; Sanzò, G.; Favero, G.; Gorton, L.; Antiochia, R. Beyond graphene: Electrochemical sensors and biosensors for biomarkers detection. Biosens. Bioelectron. 2017, 89, 152-166. [CrossRef] [PubMed]

38. Mazzei, F.; Favero, G.; Bollella, P.; Tortolini, C.; Mannina, L.; Conti, M.E.; Antiochia, R. Recent trends in electrochemical nanobiosensors for environmental analysis. Int. J. Environ. Health 2015, 7, 267-291. [CrossRef]

39. Holzinger, M.; Le Goff, A.; Cosnier, S. Nanomaterials for biosensing applications: A review. Front. Chem. 2014, 2, 63. [CrossRef] [PubMed]

40. Taurino, I.; Sanzò, G.; Antiochia, R.; Tortolini, C.; Mazzei, F.; Favero, G.; De Micheli, G.; Carrara, S. Recent advances in third generation biosensors based on $\mathrm{Au}$ and $\mathrm{Pt}$ nanostructured electrodes. Trends in Anal. Chem. 2016, 79, 151-159. [CrossRef]

41. Maduraiveeran, G.; Sasidharan, M.; Ganesan, V. Electrochemical sensor and biosensor platforms based on advanced nanomaterials for biological and biomedical applications. Biosens. Bioelectron. 2018, 103, 113-129. [CrossRef] [PubMed]

42. Jariwala, D.; Sangwan, V.K.; Lauhon, L.J.; Marks, T.J.; Hersam, M.C. Carbon nanomaterials for electronics, optoelectronics, photovoltaics, and sensing. Chem. Soc. Rev. 2013, 42, 2824-2860. [CrossRef] [PubMed]

43. Wang, Q.; Yang, Y.; Gao, F.; Ni, J.; Zhang, Y.; Lin, Z. Graphene oxide directed one-step synthesis of flowerlike graphene@HKUST-1 for enzyme-free detection of hydrogen peroxide in biological samples. ACS Appl. Mater. Interfaces 2016, 8, 32477-32487. [CrossRef] [PubMed]

44. Wang, X.; Wang, Q.; Wang, Q.; Gao, F.; Gao, F.; Yang, Y.; Guo, H. Highly dispersible and stable copper terephthalate metal-organic framework-graphene oxide nanocomposite for an electrochemical sensing application. ACS Appl. Mater. Interfaces 2014, 6, 11573-11580. [CrossRef] [PubMed]

45. Yang, Y.; Wang, Q.; Qiu, W.; Guo, H.; Gao, F. Covalent immobilization of $\mathrm{Cu}_{3}(\mathrm{btc})_{2}$ at chitosan-electroreduced graphene oxide hybrid film and its application for simultaneous detection of dihydroxybenzene isomers. J. Phys. Chem. C 2016, 120, 9794-9803. [CrossRef]

46. Gao, F.; Cai, X.; Wang, X.; Gao, C.; Liu, S.; Gao, F.; Wang, Q. Highly sensitive and selective detection of dopamine in the presence of ascorbic acid at graphene oxide modified electrode. Sens. Actuators B Chem. 2013, 186, 380-387. [CrossRef]

47. Pérez-Lópeza, B.; Merkoçi, A. Nanomaterials based biosensors for food analysis applications. Trends Food Sci. Technol. 2011, 22, 625-639. [CrossRef]

48. Della Pelle, F.; Compagnone, D. Nanomaterial-based sensing and biosensing of phenolic compounds and related antioxidant capacity in food. Sensors 2018, 18, 462. [CrossRef] [PubMed]

49. Diaconu, M.; Litescu, S.C.; Radu, G.L. Laccase-MWCNT-chitosan biosensor-A new tool for total polyphenolic content evaluation from in vitro cultivated plants. Sens. Actuators B Chem. 2010, 145, 800-806. [CrossRef]

50. Diaconu, M.; Litescu, S.C.; Radu, G.L. Bienzymatic sensor based on the use of redox enzymes and chitosan-MWCNT nanocomposite. Evaluation of total phenolic content in plant extracts. Microchim. Acta 2010, 172, 177-184. [CrossRef]

51. Chawla, S.; Rawal, R.; Sharma, S.; Pundir, C.S. An amperometric biosensor based on laccase immobilized onto nickel nanoparticles/carboxylated multiwalled carbon nanotubes/polyaniline modified gold electrode for determination of phenolic content in fruit juices. Biochem. Eng. J. 2012, 68, 76-84. [CrossRef]

52. Li, Y.; Zhang, L.; Li, M.; Pan, Z.; Li, D. A disposable biosensor based on immobilization of laccase with silica spheres on the MWCNTs-doped screen-printed electrode. Chem. Cent. J. 2012, 6, 103-110. [CrossRef] [PubMed]

53. Rawal, R.; Chawla, S.; Devender Pundir, C.S. An amperometric biosensor based on laccase immobilized onto Fe3O4NPs/cMWCNT/PANI/Au electrode for determination of phenolic content in tea leaves extract. Enzyme Microb. Technol. 2012, 51, 179-185. [CrossRef]

54. Lanzellotto, C.; Favero, G.; Antonelli, M.L.; Tortolini, C.; Cannistraro, S.; Coppari, E.; Mazzei, F. Nanostructured enzymatic biosensor based on fullerene and gold nanoparticles: Preparation, characterization and analytical applications. Biosens. Bioelectron. 2014, 55, 430-437. [CrossRef] [PubMed]

55. Zappi, D.; Nasci, G.; Sadun, C.; Tortolini, C.; Antonelli, M.L.; Bollella, P. Evaluation of new cholinium-amino acids based room temperature ionic liquids (RTILs) as immobilization matrix for electrochemical biosensor development: Proof-of-concept with Trametes Versicolor laccase. Microchem. J. 2018, 141, 346-352. [CrossRef] 
56. Nasir, M.; Nawaz, M.H.; Latif, U.; Yaqub, M.; Hayat, A.; Rahim, A. An overview on enzyme-mimicking nanomaterials for use in electrochemical and optical assays. Microchim. Acta 2017, 184, 323-342. [CrossRef]

57. Andrei, V.; Sharpe, E.; Vasilescu, A.; Andreescu, S. A single use electrochemical sensor based on biomimetic nanoceria for the detection of wine antioxidants. Talanta 2016, 156-157, 112-118. [CrossRef] [PubMed]

58. Das, M.; Patil, S.; Bhargava, N.; Kang, J.F.; Riedel, L.M.; Seal, S.; Hickman, J.J. Auto-catalytic ceria nanoparticles offer neuroprotection to adult rat spinal cord neurons. Biomaterials 2007, 28, 1918-1925. [CrossRef] [PubMed]

59. Ansari, A.A.; Solanki, P.R.; Malhotra, B.D. Hydrogen peroxide sensor based on horseradish peroxidase immobilized nanostructured cerium oxide film. J. Biotechnol. 2009, 142, 179-184. [CrossRef] [PubMed]

60. Xiao, X.L.; Luan, Q.F.; Yao, X.; Zhou, K.B. Single-crystal $\mathrm{CeO}_{2}$ nanocubes used for the direct electron transfer and electrocatalysis of horseradish peroxidase. Biosens. Bioelectron. 2010, 24, 2447-2451. [CrossRef] [PubMed]

61. Özel, R.E.; Ispas, C.; Ganesana, M.; Leiter, J.C.; Andreescu, S. Glutamate oxidase biosensor based on mixed ceria and titania nanoparticles for the detection of glutamate in hypoxic environments. Biosens. Bioelectron. 2014, 52, 397-402. [CrossRef] [PubMed]

62. Yang, X.; Ouyang, Y.; Wu, F.; Hu, Y.; Zhang, H.; Wu, Z. In situ \& controlled preparation of platinum nanoparticles dopping into graphene sheets @cerium oxide nanocomposites sensitized screen printed electrode for nonenzymatic electrochemical sensing of hydrogen peroxide. J. Electroanal. Chem. 2016, 777, 85-91. [CrossRef]

63. Ispas, C.; Njagi, J.; Cates, M.; Andreescu, S. Electrochemical Studies of Ceria as Electrode Material for Sensing and Biosensing Applications. J. Electrochem. Soc. 2008, 155, F169-F176. [CrossRef]

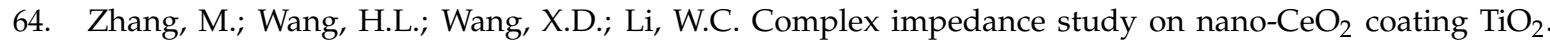
Mater. Design 2006, 27, 489-493. [CrossRef]

65. Preda, G.; Migani, A.; Neyman, K.M.; Bromley, S.T.; Illas, F.; Pacchioni, G. Formation of superoxide anions on ceria nanoparticles by interaction of molecular oxygen with $\mathrm{Ce}^{3+}$ sites. J. Phys. Chem. C 2011, 115, 5817-5822. [CrossRef]

66. Dutta, P.; Pal, S.; Seehra, M.S.; Shi, Y.; Eyring, E.M.; Ernst, R.D. Concentration of $\mathrm{Ce}^{3+}$ and oxygen vacancies in cerium oxide nanoparticles. Chem. Mater. 2006, 18, 5144-5146. [CrossRef]

67. Wang, D.; Kang, Y.; Doan-Nguyen, V.; Chen, J.; Küngas, R.; Wieder, N.L.; Bakhmutsky, K.; Gorte, R.J.; Murray, C.B. Synthesis and oxygen storage capacity of two-dimensional ceria nanocrystals. Angew. Chem. Int. Ed. Engl. 2011, 50, 4378-4381. [CrossRef] [PubMed]

68. Xu, J.; Harmer, J.; Li, G.; Chapman, T.; Collier, P.; Longworth, S.; Tsang, S.C. Size dependent oxygen buffering capacity of ceria nanocrystals. Chem. Commun. 2010, 46, 1887-1889. [CrossRef] [PubMed]

69. Heckert, E.G.; Karakoti, A.S.; Seal, S.; Self, W.T. The role of cerium redox state in the SOD mimetic activity of nanoceria. Biomaterials 2008, 29, 2705-2709. [CrossRef] [PubMed]

70. Pirmohamed, T.; Dowding, J.M.; Singh, S.; Wasserman, B.; Heckert, E.G.; Karakoti, A.S.; King, J.E.S.; Seal, S.; Self, W.T. Nanoceria exhibit redox state-dependent catalase mimetic activity. Chem. Commun. 2010, 46, 2736-2738. [CrossRef] [PubMed]

71. Asati, A.; Santra, S.; Kaittanis, C.; Nath, S.; Perez, J.M. Oxidase-like activity of polymer-coated cerium oxide nanoparticles. Angew. Chem. Int. Ed. Engl. 2009, 48, 2308-2312. [CrossRef] [PubMed]

72. Asati, A.; Kaittanis, C.; Santra, S.; Perez, J.M. The pH-tunable oxidase-like activity of cerium oxide nanoparticles achieves sensitive fluorigenic detection of cancer biomarkers at neutral pH. Anal. Chem. 2011, 83, 2547-2553. [CrossRef] [PubMed]

73. Li, X.; Sun, L.; Ge, A.; Guo, Y. Enhanced chemiluminescence detection of thrombin based on cerium oxide nanoparticles. Chem. Commun. 2011, 47, 947-949. [CrossRef] [PubMed]

74. Kaittanis, C.; Santra, S.; Asati, A.; Perez, J.M. A cerium oxide nanoparticle based device for the detection of chronic inflammation via optical and magnetic resonance imaging. Nanoscale 2012, 4, 2117-2123. [CrossRef] [PubMed]

75. Ornatska, M.; Sharpe, E.; Andreescu, D.; Andreescu, S. Paper bioassay based on ceria nanoparticles as colorimetric probes. Anal. Chem. 2011, 83, 4273-4280. [CrossRef] [PubMed]

76. Lin, Y.; Xu, C.; Ren, J.; Qu, X. Using thermally regenerable cerium oxide nanoparticles in biocomputing to perform label-free, resettable, and colorimetric logic operations. Angew. Chem. Int. Ed. Engl. 2012, 51, 12579-12583. [CrossRef] [PubMed] 
77. Celardo, I.; Pedersen, J.Z.; Traversa, E.; Ghibelli, L. Pharmacological potential of cerium oxide nanoparticles. Nanoscale 2011, 3, 1411-1420. [CrossRef] [PubMed]

78. Li, M.; Shi, P.; Xu, C.; Ren, J.; Qu, X. Cerium oxide caged metal chelator: Anti-aggregation and anti-oxidation integrated $\mathrm{H}_{2} \mathrm{O}_{2}$-responsive controlled drug release for potential Alzheimer's disease treatment. Chem. Sci. 2013, 4, 2536-2542. [CrossRef]

79. Xu, C.; Lin, Y.; Wang, J.; Wu, L.; Wei, W.; Ren, J.; Qu, X. Nanoceria-triggered synergetic drug release based on $\mathrm{CeO}(2)$-capped mesoporous silica host-guest interactions and switchable enzymatic activity and cellular effects of $\mathrm{CeO}(2)$. Adv. Healthc. Mater. 2013, 2, 1591-1599. [CrossRef] [PubMed]

80. Singh, S. Cerium oxide based nanozymes: Redox phenomenon at biointerfaces. Biointerphases 2016, 11, 04B202. [CrossRef] [PubMed]

81. Hayat, A.; Cunningham, J.; Bulbul, G.; Andreescu, S. Evaluation of the oxidase like activity of nanoceria and its application in colorimetric assays. Anal. Chim. Acta 2015, 885, 140-147. [CrossRef] [PubMed]

82. Pellegrini, N.; Re, R.; Yang, M.; Rice-Evans, C. Screening of dietary carotenoids and carotenoid-rich fruit extracts for antioxidant activities applying 2,20-azinobis (3-ethylenebenzothiazoline-6-sulfonic acid) radical cation decolourisation assay. Methods Enzymol. 1999, 299, 379-389.

83. Bard, A.J.; Faulkner, L.R. Electrochemical Methods: Fundamentals and Applications; John Wiley \& Sons: New York, NY, USA, 2001.

84. Njagi, J.; Chernov, M.M.; Leiter, J.C.; Andreescu, S. Amperometric detection of dopamine in vivo with an enzyme based carbon fiber microbiosensor. Anal. Chem. 2010, 82, 989-996. [CrossRef] [PubMed]

85. McKenzie, K.J.; Marken, F. Direct electrochemistry of nanoparticulate $\mathrm{Fe}_{2} \mathrm{O}_{3}$ in aqueous solution and adsorbed onto tin-doped indium oxide. Pure Appl. Chem. 2001, 73, 1885-1894. [CrossRef]

86. Teymourian, H.; Salimi, A.; Khezrian, $\mathrm{S}$. $\mathrm{Fe}_{3} \mathrm{O}_{4}$ magnetic nanoparticles/reduced graphene oxide nanosheets as a novel electrochemical and bioeletrochemical sensing platform. Biosens. Bioelectron. 2013, 49, 1-8. [CrossRef] [PubMed]

87. Gomes, S.A.S.S.; Nogueira, J.M.F.; Rebelo, M.J.F. A New Laccase biosensor for polyphenols determination. Sensors 2003, 3, 166-175. [CrossRef]

88. Di Fusco, M.; Tortolini, C.; Deriu, D.; Mazzei, F. Laccase-based biosensor for the determination of polyphenol index in wine. Talanta 2010, 81, 235-240. [CrossRef] [PubMed]

89. Odaci, D.; Timur, S.; Pazarlioglu, N.; Montereali, M.R.; Vastarella, W.; Pilloton, R.; Telefoncu, A. Determination of phenolic acids using Trametes versicolor laccase. Talanta 2007, 71, 312-317. [CrossRef] [PubMed]

90. Montereali, M.R.; Vastarella, W.; Della Seta, L.; Pilloton, R. Tyrosinase biosensor based on modified screen printed electrodes: Measurements of total phenol content. Int. J. Environ. Anal. Chem. 2005, 85, 795-806. [CrossRef]

91. Granero, A.M.; Fernández, H.; Agostini, E.; Zón, M.A. An amperometric biosensor based on peroxidases from Brassica napus for the determination of the total polyphenolic content in wine and tea samples. Talanta 2012, 83, 249-255. [CrossRef] [PubMed]

92. Amatatongchai, M.; Laosing, S.; Chailapakul, O.; Nacapricha, D. Simple flow injection for screening of total antioxidant capacity by amperometric detection of DPHH radical on carbon nanotube modified-glassy carbon electrode. Talanta 2012, 97, 267-272. [CrossRef] [PubMed]

(c) 2018 by the authors. Licensee MDPI, Basel, Switzerland. This article is an open access article distributed under the terms and conditions of the Creative Commons Attribution (CC BY) license (http://creativecommons.org/licenses/by/4.0/). 